\title{
类短命植物异翅独尾草的传粉特性
}

\author{
马 丞 1 2* 范俊峰市 李 静六 \\ (1 石河子大学生命科学学院, 新疆石河子 832003) \\ (2 石河子大学绿洲生态重点研究实验室, 新疆石河子 $\Lambda^{832003 \text { ) }}$
}

摘 要 该文对生长于新疆古尔班通古特沙漠的类短命植物异翅独尾草 (Eremurus anisopterus) 的传粉习性做了观察 研究 结果如下: 异翅独尾草的花期从 4 月下旬至 5 月中旬, 单花花期一般为 $1 \mathrm{~d}$, 而当遭遇最高温度不足 $20^{\circ} \mathrm{C}$ 的阴 雨天气时 单花花期可延长至 $2 \mathrm{~d}$ 。单花的开花时间一般为每天 10:30 15:00, 大约 4 5 h 单个花药的散粉时间约 为 $40 \mathrm{~min}$, 但其 6 枚花药的开裂与散粉具有明显的不同步性, 显著地延长了单花的散粉时间, 这是对干热多风的沙 漠生境中传粉者不确定性高度适应的结果。异翅独尾草花粉借风传播的距离可达 $70 \mathrm{~m}$, 但其中约 $60 \%$ 花粉的散布 距离集中在 $20 \mathrm{~m}$ 以内; 昆虫是异翅独尾草的重要传粉媒介, 蜜蜂、食蚜蝇、麻蝇、切叶蜂、隧蜂等是主要的传粉者。 蜜蜂和食蚜蝇访花时, 都是先飞落到花基部黄绿色斑点处, 然后沿着花被片的紫色脉纹进入到花内, 黄绿色斑点是 对花蜜的拟态, 是异翅独尾草对高温多风沙环境高度适应的结果。昆虫的访花行为最活跃的时间在 10:30 13:30 之间。一天当中单花的开放时间与沙漠中风速的日变化及访花昆虫的活动习性之间呈现出显著的相关性。异翅 独尾草的花粉与胚珠比 $(\mathrm{P} / \mathrm{O})$ 等于 6164 , 为适合于异花传粉的类型。人工套袋试验结果表明自交是可育的,这可 能是对占据了不稳定的、先锋生境的异翅独尾草缺乏远交机会的有效补偿。不存在无融合生殖现象。

关键词 类短命植物 异翅独尾草 传粉 雄蕊异时发育 花粉/胚珠

\section{POLLINATION CHARACTERISTICS OF EPHEMEROID PLANT EREMURUS ANISOPTERUS}

\author{
MA Miao ${ }^{12 *}$ FAN Jun-Feng $\frac{1}{\bar{A}}$ and LI Jing $\frac{1}{\bar{y}}$ \\ ( 1 College of Life Science, Shihezi University, Shihezl , Xinjiang 832003 , China) \\ (2) The State Key Laboratory of Oacis Ecology, Shihezi Uniwersity, Shihezi, Xinjuang $\lambda^{8} 82003$, China)
}

Abstract Background and Aims This study was conducted to examine the pollination characteristics of Eremurus anisopterus, an ephemeroid plant in Gurbantunggut Desert in Xinjiang , China.

Methords An integratve approach combining investigation in field with analysis in lab was adopted. Pollen traps were usded to measure air-borne pollen loads, and artificial isolation experiments were applied to test the potentiality of cross-pollination or apomixes.

Key Results Duration of flowering of Eremurus anisopterus varied from late April to middle May. Anthesis of a single flower often lasted for $1 \mathrm{~d}$. However, if the daily maximum air temperature was under $20{ }^{\circ} \mathrm{C}$, the anthesis of a single flower could be prolonged to $2 \mathrm{~d}$. Pollen-dispersion period of single flower could last for 4 to $5 \mathrm{~h}$ from 10:30 to 15:00 local time with the duration of pollen dispersion for single anther approximately 40 $\min$. The heterotypical maturation of stamina could significantly prolonged the pollen-dispersion period of a single flower, suggesting an adaptation to the habitat of $E$. anisopterus in the desert where the pollinators were not reliable. The timing of blossom of the ephemeroid plant showed close correlations with wind velocity , habit and characteristics of the pollinators in the desert. Pollens of the plant might spread over $70 \mathrm{~m}$ by wind with approximately $60 \%$ of the pollens fallen within $20 \mathrm{~m}$ away from the plant. Insects, especially bee, hover fly, flesh fly , mason bee and Halictus sp. were very important pollination medium. Visitors, such as bee and hover fly, usually landed at the yellowish green spot on the tepal, and then entered the flower along the purple vein on the pink tepals. The yellowish green spot might be a mimetic structure to nectar that could attract insects to visit, which was also the result of the long-period adaptation of the plant to its sandy desert habitat. Higher visiting frequency was reached between $10: 30$ and $13: 30$. The $\mathrm{P} / \mathrm{O}$ of $E$. anisopterus (6 164) suggested the species was of cross-pollination characteristic according to Cruden's criterion. However, artificial isolation experiment showed that $E$. anisopterus was self-compatible, which might act as a compensation 
mechanism for the inadequate outbreeding chances in the desert habitat. The fact that there was no seed set in bagged emasculated flowers indicated that there was no apomixes occur.

Conclusions This study suggests that $E$. anisopterus might adapt the not-reliable pollinator habitat by selfcompatible and lengthening pollen-dispersion period of single flower.

Key words Ephemeroid plant, Eremurus anisopterus , Pollination , Heterotypical maturation of stamina , P/O

短命植物是一类利用开春积雪融化、春雨开始、 气温和暖、土壤湿润的有利条件, 在 2 个月左右的时 间迅速完成整个生长发育过程的特殊草本植物类群 (王烨, 1993 )。包括狭义的一年生短命植物 (Ephemeral plant) 和多年生类短命植物 (Ephemeroid plant), 前者当年完成生活周期、翌年春季由种子形 成新个体，以种子度过干热夏季和作为越冬的器官 ; 后者是指生活周期十分短促的多年生植物, 其地上 部分特性与一年生短命植物相似，但具有宿存的多 年生根状茎、球茎、块茎、块根等, 它们在短周期内抽 生花茎, 开花, 然后以耐旱、耐寒的地下器官度过干 热的夏季和寒冷的冬季 (冯德培等,1983)。来年春 天可由种子萌发形成新个体或由地下芽生长形成新 植物体。作为群落下层的主要建造者,一年生短命 植物和类短命植物在 3 月下旬至 6 月形成明显的层 片, 这正是北疆沙漠呈现固定、半固定性的重要因素 之一(胡适之等,1962 炼治平, 1963; 吴正, 1997)。

异翅独尾草 (Eremurus anisopterus) 系百合科独尾 草属植物 (中国植物志编辑委员会, 1980 )。仅分布 于新疆古尔班通古特沙漠固定、半固定沙丘及沙地, 为典型的沙生类短命植物。以其为代表的早春类短 命植物, 是古尔班通古特沙漠稳定沙面植被的主要 贡献者(王雪芹等 2003a) 以及维持荒漠生态系统的 主要参与者。但是近半个世纪以来, 受强烈的人为 活动影响, 诸如修建沙漠公路、钻探和采油占地、铺 设输油(气) 管道和开挖供水渠道以及所有工程的附 属设施等 给沙漠植被带来了厄运 给对外界因素的 影响极其敏感的古尔班通古特沙质荒漠生态系统带 来了历史性的灾难(张立运等, 1998)。研究证明, 短 命植物是人类活动扰动沙面后生态恢复的先锋物种 (王雪芹等, 2003a)。因此, 作为我国荒漠植物区系 中重要而独特的组成部分, 短命植物引起了一些植 物学者的关注, 研究主要集中于植物区系、植物地 理、物候学、生态生物学等 (郑度, 1960;刘瑛心, 1982 陈昌笃等, 1983 张立运, 1985; 刘晓云, 1992; 王 烨, 1993; 毛祖美和张佃民, 1994; 李向义,2000)。但 现有文献中缺乏从传粉生态学的角度研究沙生短命 植物生态适应机理, 尤其是对沙生短命植物的传粉 习性及其对环境的生态适应性方面的研究目前尚无
报道。因此, 本文从花粉与胚珠比 (Pollen-ovule ratio，P/O)、繁育系统 (Breeding system)、雄莈异熟 (Heterotypical maturation of stamina) 及昆虫的访花行 为、访花频次入手对分布在新疆古尔班通古特沙漠 中的类短命植物异翅独尾草的传粉特性进行了研 究。旨在确定异翅独尾草繁育系统的类型及其生态 适应机理, 为该类群植物的保护与利用提供科学参 考。

\section{1 材料和方法}

\section{1 研究材料和观察地点}

异翅独尾草属沙生类短命植物，高 $40 \sim 60 \mathrm{~cm}$; 叶长条形基生成丛; 总状花序宽阔而舒展;两性花， 花被片 6 枚, 粉红色, 背面中央有一条紫色脉纹, 基 部有黄绿色斑点; 雄范 6 枚; 花柱细长, 先端呈钩状 向上弯曲 柱头针状; 子房 3 室, 蒴果近球形。

采样地点为古尔班通古特沙漠南缘 $\left(44^{\circ} 45^{\prime} \mathrm{N}\right.$, $85^{\circ} 55^{\prime} \mathrm{E}$ 海拔 $344 \mathrm{~m}$ ) 控制本区域的风系主要是从 西部各山谷和山口进入的西风气流和冬季蒙古高压 形成的东北风系。起沙风 $\left(\geqslant 6 \mathrm{~m} \mathrm{~s}^{-1}\right)$ 集中于 $4 \sim 9$ 月 其中以 4、5、6 月最为强盛 (王雪芹等, 2003b)。 该区气候干燥, 气温变化大, 年积温 $3000 \sim 3500$ ${ }^{\circ} \mathrm{C}$, 年降水量 $70 \sim 150 \mathrm{~mm}$,年蒸发量 $2000 \mathrm{~mm}$ 以 上, 为典型的内陆干旱气候。其水分主要来源于降 雨和雪融, 凝结水也有一定的作用。冬季稳定积雪 期可达 $70 \sim 130 \mathrm{~d}$, 厚度 $10 \sim 25 \mathrm{~cm}$, 春季融化后形成 $50 \sim 60 \mathrm{~cm}$ 厚的悬湿沙层, 为荒漠植物特别是短命、 类短命植物的生长创造了良好的条件 (季方等, 2000 ; 王雪芹等 , 2003b)。

\section{2 花期生物学特性的观察}

$2004 \sim 2005$ 年连续两年在自然种群中选择生长 良好的即将开放的异翅独尾草的花，观察并记录整 个花期。每次选择 20 朵进行标记，从 8:00 16:00 连续观察, 记录单花的开放与花药散粉行为、花被片 的形态变化以及 6 枚雄莎散粉的不同步性, 记录观 测结果。

\section{3 花粉量与胚珠数比 $(\mathrm{P} / \mathrm{O})$ 的估算}

随机选取刚开放而花药尚未开裂的花 10 朵, 用 $75 \%$ 的乙醇水溶液固定, 迅速带回实验室。取单花 


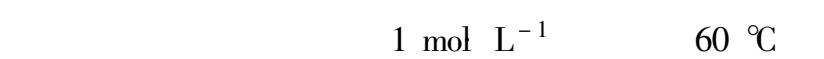
浴中加热 $15 \mathrm{~min}$, 水解药壁法去药壁 然后滴加蒸馏 水, 制成 $50 \mathrm{ml}$ 花粉粒悬浮液, 用移液器准确吸取 5 $\mu \mathrm{l}$ 的花粉悬浮液置于洁净的载玻片上, 在 Olympus 光学显微镜下统计花粉量。重复取样 10 次, 求得平 均每朵花总花粉量。然后取每朵花的子房在体式显 微镜下解剖, 记录单花中的胚珠数, 求得平均每朵花 的胚珠数。用单花花粉量除以单花总胚珠数, 即为 $\mathrm{P} / 0$ 比。

\section{4 传粉媒介和繁育系统检测}

在自然种群中选定花粉源, 采用重力玻片法按 顺风方向从花粉源开始, 每间隔 $1 \mathrm{~m}$ 设置简易花粉 捕捉器 (用 1 片载玻片正面涂上医用凡士林) , 平行 放置两列各 70 片。每日上午 9:00 左右放置, 下午 17:00 左右取回, 以检测风对花粉流的影响。观察 昆虫访花行为, 以每 $1 \mathrm{~h}$ 为一个时间统计单位, 随机 标记 10 朵单花, 观察和记录整个单花期昆虫的访花 行为, 访花次数及访花频率。捕捉访花昆虫将其迅速 致死后, 带回实验室进行种类鉴定并镜检携带花粉的 情况。在自然种群中对尚未开放的花(花序下部已经 开放的除去)分别做如下处理 :对照(不作任何处理， 标记)、人工去雄套袋 (去除花药)、自然套袋 (开花前 直接套袋)，每种处理 10 株，200 朵花，待果实成熟后 分别收获种子并统计结实率 (种子数/果实数)。

\section{2 观察结果}

\section{1 花期和花药散开的特性}

2004 年异翅独尾草的始花期为 4 月 28 日, 初花 期为 4 月 30 日, 盛花期约为 5 月 $1 \sim 12$ 日，末花期 为 5 月 14 日，完花期为 5 月 17 日，2005 年始花期为 4 月 27 日, 初花期为 4 月 29 日, 盛花期约为 5 月 1 10 日，末花期为 5 月 12 日，完花期为 5 月 16 日。单 株花序的开花次序为由基部向顶部推进, 单花花期 一般为 $1 \mathrm{~d}$,开花时间为每天 10:30 15:00, 而当遭 遇最高温度不足 $20{ }^{\circ} \mathrm{C}$ 的阴雨天气时, 单花花期可延 长至 $2 \mathrm{~d}$ 。单枚花药的散粉时间一般为 $40 \mathrm{~min}$, 但 6 枚花药的开裂与散粉具有明显的不同步性,6枚花 药逐枚依次开裂或两两开裂, 整个单花散粉时间为 $4 \sim 5 \mathrm{~h}$, 因此显著地延长了单花散粉时间。花药干 癔后, 花被片萎蒸闭合。

\section{$2.2 \mathrm{P} / \mathrm{O}$ 比}

异翅独尾草雄芯单个花药的平均花粉量为 17466 粒, 每朵花 6 枚雄蕊, 平均单花花粉量为 104800 粒;平均单花胚珠数 17 枚; 故 $\mathrm{P} / \mathrm{O}$ 比为 6
164。参照 Cruden ( 1977) 花粉胚珠比 (P/O) 划分繁 育系统类型, $\mathrm{P} / \mathrm{O}$ 比位于区间 $(2.7,5.4)$ 时为闭花授 粉，位于区间( $18.1,39.0)$ 时为专性自交，位于区间 $(31.9,396.0)$ 时为兼性自交，位于区间 (244.7, 2588.0 ) 时对应着兼性异交,位于区间(2108.0， 195 525.0)时为专性异交的交配系统。异翅独尾草 为专性异交的交配系统。

2.3 花粉的散布、访花昆虫的种类、访花行为以及 访花频率

通过在显微镜下镜检发现，在载玻片上有异翅 独尾草花粉存在, 证明了风媒传粉的可能性。异翅 独尾草花粉借风散布的距离至少可达 $70 \mathrm{~m}$, 但随着 散布距离的增加花粉数量逐渐减少 (图 1)。不论是 在 1 级风还是在 4 级风的情况下, 大约 $60 \%$ 花粉的 散布距离集中在 $20 \mathrm{~m}$ 以内。自然种群中 花开放后 访花的动物有蜘蛛、蚂蚁和多种昆虫, 镜检发现至少 有 6 种昆虫体表携带花粉, 分别隶属于蜜蜂科、食蚜 蝇科、麻蝇科、切叶蜂科以及隧蜂科对异翅独尾草的 传粉事件有直接贡献 (连续两年的观察)。蜜蜂和食 蚜蝇的访花行为特别, 都是先飞落到花被片基部的 黄绿色斑点处 然后沿着花被片上的紫色脉纹进入 到花内。尽管蜘蛛、蚂蚁体表有时也会携带异翅独 尾草的花粉, 但花粉量很少, 且其活动过程中与柱头 接触的机会很少, 所以认为蜘蛛和蚂蚁都不是有效 传粉者。但在遭遇到阴雨天气或温度较低，即日最 高气温小于 $20^{\circ} \mathrm{C}$ 时, 沙漠中一般见不到访花昆虫的 活动。从图 2 可以看出昆虫的访花行为最活跃的时 间在 10:30 13:30之间。

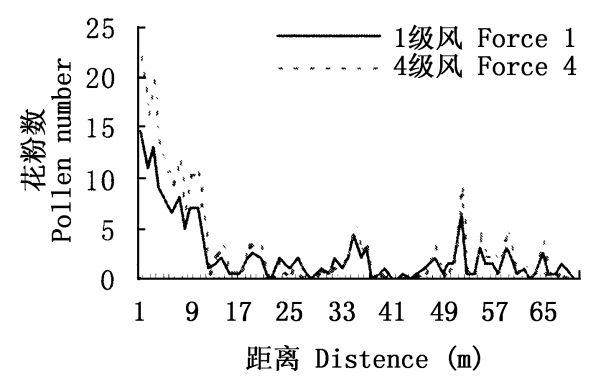

图 1 异翅独尾草花粉风力散布图

Fig.1 Pollen dispersal of Eremurus anisopterus by wind

\section{4 繁育系统}

异翅独尾草地下肉质根是一个能量存储器官， 异翅独尾草借此能安全地度过干旱高温的夏季和寒 冷的冬季。翌年春, 当积雪融化滋润了沙层后, 可由 地下芽萌生 (Sprout) 出新植物体, 开花结果进行有性 
生殖。在自然种群中, 自然套袋的植株可以形成果 实和种子(表 1 ), 说明异翅独尾草单株自花受精是
可能的。人工去雄套袋的植株果实虽然可以膨大， 但无种子形成, 说明不存在无融合生殖现象。

表 1 不同处理材料的结实率比较

Table 1 Comparison of seed-set ratio among different treatments

\begin{tabular}{lccc}
\hline & & \multicolumn{2}{c}{ 处理 Treatments } \\
\cline { 2 - 5 } & $\begin{array}{c}\text { 对照 } \\
\text { Control }\end{array}$ & $\begin{array}{c}\text { 去雄套袋 } \\
\text { Removed anthers and bagged }\end{array}$ & $\begin{array}{c}\text { 自然套袋(开花前直接套袋) } \\
\text { Bagged directedly (bagged before flowering) }\end{array}$ \\
\hline 结实数 Number of fruits $(N)$ & 198 & 123 & 192 \\
种子数 Number of seeds $(n)$ & 2475 & 0 & 2150 \\
结实率 Seed-set ratio $(n / N)$ & 12.5 & 0 & 11.2 \\
\hline
\end{tabular}

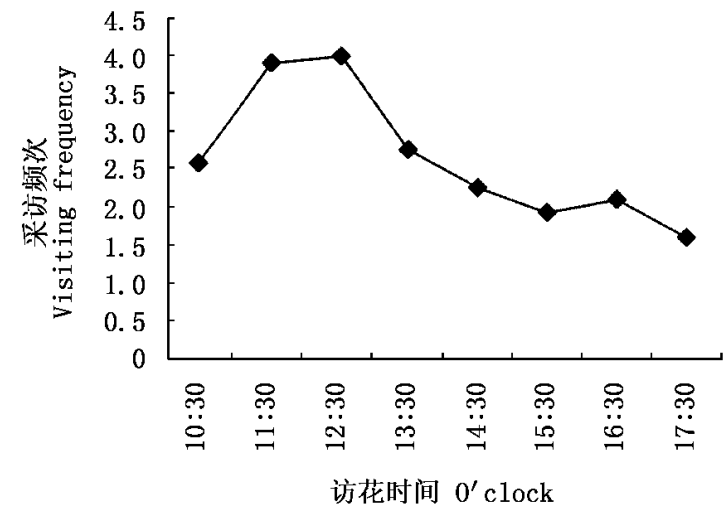

图 2 平均每朵花被访花者采访频次

Fig.2 Vsiting frequency of visitors to each flower onaverage

\section{3 结论与讨论}

3.1 异翅独尾草吸引昆虫的策略

花部结构及特征对访问者行为和花粉传递机制 的影响，反过来又作用于植物作为雌性 (花粉受体) 和雄性 (花粉供体) 亲本的繁殖成功率 (Spira et al. , 1992 ;Fishbein \& Venable，1996)。鲜艳、美丽的花朵 可以吸引昆虫, 既能把花粉带来使这个植物的胚珠 受精, 又能把这个植物的花粉带给别的植物使它们 的胚珠受精(张大勇和姜新华,2001)。维持花与传 粉者这种关系的往往是蜜腺、花粉、气味以及花色等 被称之为 诱物”的花部综合特征。因为花部的变异 往往伴随传粉生态的变化, 花部结构与繁育系统特 别是传粉者的习性必定是一起进化起来的 (黄双全 等, 1999)。异翅独尾草花部结构及其特征可概括如 下:1)异翅独尾草花被片呈粉红色, 大而鲜艳,6枚 花被片中下部 3 片构成了昆虫采粉时立足的平台， 花柱先端呈钩状向上弯曲, 增大了柱头接受自花花 粉及访花昆虫体表花粉的机会。由于沙漠的气温白
天很高，而上部的 3 片则形成了 遮阳棚”, 为身处炎 热沙漠中的访花昆虫营造了相对适宜的访花环境。 2)在花被片基部具有形似蜜腺的黄绿色拟态斑点， 是吸引蜜蜂及食蚜蝇等昆虫的访花行为的特征诱 物，因为这些昆虫总是先飞落到该黄绿色斑点处 然 后再沿着花被片的紫色脉纹进入花内。3)雄芯具有 异时发育的特点。在干旱、炎热、多风的沙漠环境 中 花药散粉时间是短暂的且昆虫的活动受到极大 的限制。生产出来的花粉如果要完全扩散出去则需 要昆虫多次访问 (张大勇和姜新华,2001)。雄荵发 育的不同步性是对昆虫行为的高度适应,6枚花药 的散粉事件具有明显的不同步性, 客观上延长了单 花的散粉时间, 提高了在整个散粉期遇到传粉昆虫 的可能性，对提高传粉效率是很有适应意义的。

3.2 异翅独尾草的传粉特性是对沙漠极端环境高 度适应的结果

对植物交配系统变异影响最大的生态因子莫过 于植物的传粉模式, 其中最直接的作用表现为环境 因子(如风、温度、湿度等) ,对传粉者和花粉柱头之 间相互关系的影响。植物在花期遇到不利的天气势 必影响到访花者的类型和数量, 进而影响到植物交 配过程的正常进行和有性生殖的成功率。影响传粉 的环境因子主要有 :1) 沙漠中的风沙气候极大的影 响了访花昆虫的行为。异翅独尾草生长的环境中风 力较大, 当风力达到 4 级时, 几乎没有访花昆虫活 动，但是中午 11:00 左右风力逐渐减小，下午 14:00 左右风力最小。而这段时间恰好与异翅独尾草的开 花时间相一致 (10:30 15:00)。异翅独尾草要使自 身传粉效率达到最高, 散粉期与昆虫的活动频率必 须高度保持一致。2) 沙漠中常表现为高温、干燥, 多 风沙的气候状况。在这种恶劣的环境下, 花蜜很容 易被快速蒸发干,或者起风时易粘连沙粒而失去了 吸引昆虫的作用。且沙漠中沙土养分差、土壤贫痊, 
异翅独尾草的生长期很短 (约 $60 \mathrm{~d}$ ), 既要营养生长 (地下越冬的根、地上茎叶生长), 又要保证大量种子 的形成，势必有所权衡，所以未形成蜜腺而只有黄绿 色的拟态斑点不仅是对高温与风沙环境的适应, 也 是节约能量权衡的结果。3)一般来说, 恶劣传粉条 件应该导致自交率上升，因为自交花粉的竞争对手 一异交花粉——到达柱头的数量减少。而且, 花 粉与柱头的时空分离程度在不良环境条件下可能会 有所下降 (Lloyd \& Schoen,1992 ;张大勇和姜新华, 2001)。Schoen 和 Brown (1991) 提供的证据表明, 造 成不良传粉的环境条件确实可以诱导自交发生。沙 漠中的恶劣环境必然导致传粉者的不可靠性并使异 交率下降，传粉者的不可靠性并使异交率下降的同 时,必然引起自交率增长的潜在趋势。

Stebbins (1970)认为从专性远交向自交的转变, 主要并可能是严格地发生在那些占据了不稳定或是 先锋生境的植物中, 异翅独尾草所生存的沙漠依然 属于演替早期的先锋生境, 这样异交率下降、自交率 上升以及自花传粉都可以被认为是对缺少远交机会 的补偿, 在保证物种的种族繁衍方面具有重要的现 实意义。

\section{参 考 文 献}

Chen CD (陈昌笃), Zhang LY (张立运), Hu WK (胡文康)

(1983). The basic characteristics of plant communities, flora and their distribution in the sandy district of Gurbantunggut. Acta Phytoecologica et Geobotanica Sinica (植物生态学与地植物学 丛刊) , 7, 89-99. (in Chinese with English abstract)

Chen ZP (陈治平) (1963). The characteristics of Gurbantunggut Desert in Junggar Basin. In: Institute of Geography of Chinese Academy of Sciences (中国科学院地理研究所) ed. Collected Geography Works (No.5) (地理集刊 (第 5 号)). Science Press, Beijing, 79-90. (in Chinese)

Cruden RW (1977). Pollen-ovule ratios: a conser-vative indicator of breeding systems in flowering plants. Evolution, 31, 32-46. Editorial Board of the Flora of China (中国植物志编辑委员会) (1980). Flora of China Vol.14 (中国植物志第 14 卷). Science Press, Beijing, 80. (in Chinese)

Feng DP (冯德培), Tan JZ (谈家桢), Wang QM (王岐鸣) (1983). Concise Biological Dictionary (简明生物学词典). Shanghai Lexicographical Publishing House, Shanghai, 1022. (in Chinese)

Fishbein M, Venable DL (1996) . Diversity and temporal change in the effective pollinators of Asclepias tuberosa. Ecology, 77, 1061 -1073 .
Huang SQ (黄双全), Guo YH (郭友好), Pan MQ (潘明清), Chen JK (陈家宽) (1999). Floral syndrome and insect pollination of Liriodenron chinense. Acta Botanica Sinica (植物学报), 41, 241 - 248. (in Chinese with English abstract)

Hu SZ (胡适之), Lu YT (卢云亭), Wu Z (吴正) (1962). The scientific investigation of the desert of Junggar Basin in Xinjiang. In: Sand Control Team, the Chinese Academy of Sciences (中国 科学院治沙队) ed. Researches on Sand Control (No.3) (治 沙研究(第 3 号)). Science Press, Beijing, 43-64. (in Chinese)

Ji F(季方), Ye W (叶玮), Wei WS(魏文寿) (2000). Preliminary study on the formation causes of the fixed and semi-fixed dunes in Gurbantonggut desert. Arid Land Geography (干旱区 地理), 23, 32-36. (in Chinese with English abstract)

Li XY (李向义) (2000). Preliminary studying the characteristic of roots and relations between roots and environment of ephemerals in Xinjiang. Arid Zone Research (干旱区研究), 17(3), 28 34. (in Chinese with English abstract)

Liu XY (刘晓云) (1992). The ecological and biological characteristics of ephemeral and ephemeroids. Arid Zone Research (干旱 区研究), 9 (Suppl.), 46-55. (in Chinese with English abstract)

Liu YX (刘瑛心) (1982). Observations on the for-mation of Chinese desert flora. Acta Phytotaxonomica Sinica (植物分类学 报), 20, 131 - 141. (in Chinese with English abstract)

Lloyd DG, Schoen DJ (1992). Self-fertilization and cross-fertilization in plants. I. Functional dimensions. International Journal of Plant Science, 153, 358-369.

Mao ZM (毛祖美), Zhang DM (张佃民) (1994). The conspectus of ephemeral flora in northern Xinjiang. Arid Zone Research (干旱区研究) , 11(3), 1-26. (in Chinese with English abstract)

Schoen DJ, Brown AHD (1991). Whole-and part-flower self-pollination in Glycine argyrea and G. clandestine and the evolution of autogamy. Evolution, 45, $1651-1665$.

Spira TP, Snow AA, Whigham DF, Leak JL (1992) . Flower visitation, pollen deposition, and pollen-tude competition in Hibiscus moscheutos (Malvaceae). American Journal of Botany, 79, 428 -443 .

Stebbins GL (1970). Adaptive radiation of reproductive characteristics in angiosperms. I. Pollination mechanisms. Annual Review of Ecology and Systematics, 1, $307-326$.

Wang XQ (王雪芹), Jiang J (蒋进), Lei JQ (雷加强), Zhang WM (张伟民), Qian YB (钱亦兵) (2003a). The distribution of ephemeral vegetation on the longitudinal dune surface and its stabilization significance in the Gurbantunggut Desert. Acta 
Geographica Sinica (地理学报), 58, 598 - 605. (in Chinese with English abstract)

Wang XQ (王雪芹), Li BW (李丙文), Zhang YM (张元明) $(2003 \mathrm{~b})$. Stabilization of dune surface and formation of mobile belt at the top of longitudinal dunes in Gurbantunggut Desert, Xinjiang, China. Journal of Desert Research (中国沙漠), 23 (2), 126 - 131. ( in Chinese with English abstract)

Wang Y (王烨) (1993). Phenological observation of the early spring ephemeral and ephemeroid plant in Xinjiang. Arid Zone Research (干旱区研究), 10(3), 34 - 39. (in Chinese with English abstract)

Wu Z (吴正) (1997). Preliminary study on the aeolian sand landforms in Junggar Basin. In: Wu Z (吴正) ed. Study on the Desert and Coast in China (中国沙漠与海岸沙丘研究). Science Press, Beijing, 29-43. (in Chinese)

Zhang DY (张大勇), Jiang XH (姜新华) (2001). Mating system evolution, resource allocation, and genetic diversity in plants.
Acta Phytoecologica Sinica (植物生态学报), 25, 130 - 143. (in Chinese with English abstract)

Zhang LY (张立运) (1985). A preliminary study on the ephemerals of Mosowan District, Xinjiang. Acta Phytoecologica et Geobotanica Sinica (植物生态学与地植物学丛刊), 9, 213-222. (in Chinese with English abstract)

Zhang LY (张立运), Liu S (刘速), Zhou XJ (周兴佳), Huang Q (黄强) (1998). The affection of engineering action on the vegetation in the Gurbantunggut Desert. Arid Zone Research (干 旱区研究), 15 (4), 15 - 19. (in Chinese with English abstract)

Zheng D (郑度) (1960). Study on the desert vegetation and its environment in Junggar Desert. In: Sand Control Team, the Chinese Academy of Sciences (中国科学院治沙队) ed. Collected Research Works of the First Sand Control Conference, CAS (中国 科学院治沙队第一次学术报告会文集), 1 - 11. (in Chinese) 